\title{
Efficacy of Prophylactic use of Ciprofloxacin and Metronidazole in Mild and Moderately Severe Acute Pancreatitis
}

\author{
Amrendra Kumar Mandal, ${ }^{1}$ Sitaram Chaudhary, ${ }^{1}$ Barun Shrestha, ${ }^{1}$ Mukesh Sharma Paudel, ${ }^{1}$ Nandu Silwal \\ Poudyal, 'Bidhan Nidhi Paudel, ${ }^{1}$ Bikash Bhattarai, ${ }^{2}$ Sunil Kumar Ray, ${ }^{3}$ Neetu Mandal Ray ${ }^{4}$ \\ 'Gastroenterology Unit, Department of Medicine, NAMS, Bir Hospital, Kathmandu, Nepal, ${ }^{2}$ Interfaith Medical Center, \\ Brooklyn, NY, USA, ${ }^{3}$ Sure Medical PC, Elmhurst, NY, USA, ${ }^{4}$ New York Presbyterian Hospital, Queens, NY, USA.
}

\section{ABSTRACT}

Introduction: There are new concepts and developments in the diagnosis and management of acute pancreatitis. Current evidence suggests that there is no role of prophylactic antibiotics use in acute pancreatitis. However, it is still a common practice to administer prophylactic antibiotics in a country like Nepal. So, we have conducted a study in mild and moderately severe acute pancreatitis to study the efficacy of prophylactic antibiotics.

Methods: A case control study was conducted among 76 patients comparing efficacy of prophylactic antibiotics versus no antibiotics in patients with mild and moderately severe acute pancreatitis.

Results: The two most common etiology of acute pancreatitis in AG and NAG were alcohol 21 $(55.2 \%)$ vs. $24(63.1 \%)$ and biliary $10(26.3 \%)$ vs. $4(10.5 \%)$ respectively. Pancreatic necrosis was seen in five $(13.1 \%)$ in AG and four $(10.5 \%)$ in NAG. Four $(10.5 \%)$ developed extra pancreatic complications in AG and five (13.1\%) in NAG. There was one (2.6\%) death in AG and no death in NAG. Abdominal pain improvement seen in AG vs. NAG was 3.2 days vs. 2.4 days $(\mathrm{P}=0.002)$. The hospital stay was $7.7 \pm 2.23$ days in $A G$ and $7.5 \pm 1.85$ days in NAG $(P=0.65)$.

Conclusions: The routine use of prophylactic antibiotics for mild and moderately severe acute pancreatitis is not associated with improvement in meaningful clinical outcomes.

Keywords: Atlanta classification 2012; mild acute pancreatitis; moderately severe acute pancreatitis; prophylactic antibiotic.

\section{INTRODUCTION}

There are new concepts and developments in the diagnosis and management of acute pancreatitis. There have been important changes in the "revised Atlanta classification" since the Atlanta classification from 1992. ${ }^{1,2}$ In mid-2000, it was reported that there is no role of prophylactic antibiotics based on the two landmark trials. ${ }^{3,4}$

However, infectious complications from acute pancreatitis account for high morbidity and mortality with $80 \%$ of deaths related to infectious complications. ${ }^{5}$ The mortality rate due to organ failure has been recently reported between $36-50 \%$ in two different studies. ${ }^{6,7}$

So, we aimed to ascertain the efficacy of prophylactic antibiotics to prevent pancreatic and peripancreatic infections as well as the effect of reduction in the 
morbidity and mortality in our setup where many clinicians still prefer to administer prophylactic antibiotics. ${ }^{1}$

\section{METHODS}

This was a case control study comparing efficacy of prophylactic antibiotics vs. no antibiotics. The study was conducted in the ward and/or ICU at Bir Hospital, NAMS from June 2015 to May 2017. Ethical approval was taken from the Institutional Review Board (IRB) of the Bir Hospital, NAMS. Patients written consent were taken from participants. Sample size was calculated using following formula:

$$
\begin{aligned}
& \mathrm{P}_{1}=14.6 \%, \mathrm{P}_{2}=48.5 \%, \mathrm{P}=\left(\mathrm{p}_{1}+\mathrm{p}_{2}\right) / 2 \mathrm{n} \\
& \mathrm{n}=\left[\frac{\mathrm{z}_{\alpha} \sqrt{2 p(1-p)}+\mathrm{z}_{\beta} \sqrt{p_{1}\left(1-p_{1}\right)+p_{2}\left(1-p_{2}\right)}}{\left(p_{1}-p_{2}\right)}\right]^{2}
\end{aligned}
$$

38 samples were enrolled in each of the antibiotic group (AG) and non-antibiotic group (NAG). We enrolled patients who presented within 72 hours of onset of abdominal pain. Acute pancreatitis was diagnosed based on revised Atlanta classification 2012.1,2 All the participants underwent Contrast Enhanced Computerized Tomography (CECT) abdomen unless contraindicated and they were stratified into either AG or NAG. Patients diagnosed with any infections, either pancreatic or extra pancreatic or severe acute pancreatitis during admission were excluded from the study as the restriction of antibiotics use in severe acute pancreatitis might be difficult in preventing clinicians from administering it. Patients who refused to give consent were also excluded. Patients were consecutively enrolled and immediately received a combination of Ciprofloxacin $400 \mathrm{mg}$ intravenously daily in two divided doses with Metronidazole 500 mg intravenously thrice daily. Same brand of antibiotics was used in all the patients. The antibiotics were administered to every alternate patient enrolled in this study. Initially, IV antibiotics were administered and later switched over to oral antibiotics once the patients were able to take orally. The total duration of antibiotics was 14 days. Data were collected and analyzed in Statistical Package for Social Sciences version (SPSS) 22. A p-value of less than 0.05 was taken as statistically significant. The chisquare and independent t-test were used to compare the results.

\section{RESULTS}

Out of 76 enrolled participants (38 in $A G$ and 38 in NAG), male participants were $12(31.5 \%)$ in $A G$ and $6(15.7 \%)$ in NAG. There was no difference in mean age, etiology, mean arterial pressure (MAP), severity of abdominal pain and in the number of participants with mild and moderately severe acute pancreatitis in both

\begin{tabular}{|c|c|c|c|}
\hline Characteristics & $\begin{array}{l}\text { Antibiotic } \\
(n=38) \\
n(\%) \text { or } \\
\text { Mean } \pm \text { SD }\end{array}$ & $\begin{array}{l}\text { No Antibiotic } \\
(\mathrm{n}=38) \\
\mathrm{n}(\%) \text { or Mean } \\
\pm \text { SD }\end{array}$ & $\begin{array}{l}\text { P- } \\
\text { value }\end{array}$ \\
\hline Age (years) & $47 \pm 11.76$ & $48.77 \pm 14.77$ & 0.55 \\
\hline \multicolumn{4}{|l|}{$\begin{array}{l}\text { Etiology } \\
\text { of acute } \\
\text { pancreatitis }\end{array}$} \\
\hline Alcohol & $21(55.2)$ & $24(63.1)$ & 0.29 \\
\hline Biliary & $10(26.3)$ & $4(10.5)$ & 0.077 \\
\hline $\begin{array}{l}\text { Hypertrigly } \\
\text { ceridemia }\end{array}$ & $1(2.6)$ & $2(5.2)$ & 1 \\
\hline $\begin{array}{l}\text { Hyperpar at } \\
\text { hyroidism }\end{array}$ & $1(2.6)$ & $2(5.2)$ & 1 \\
\hline Unknown & $5(13.1)$ & $6(15.7)$ & 0.47 \\
\hline MAP (mm Hg) & $85.33 \pm 9.29$ & $86.62 \pm 9.55$ & 0.5 \\
\hline \multicolumn{4}{|c|}{ Abdominal Pain } \\
\hline Mild & 12 & 14 & 1 \\
\hline Moderate & 18 & 19 & 0.82 \\
\hline Severe & 8 & 5 & 0.15 \\
\hline \multicolumn{4}{|l|}{$\begin{array}{l}\text { Severity of } \\
\text { pancreatitis }\end{array}$} \\
\hline Mild & 25 & 24 & 0.85 \\
\hline $\begin{array}{l}\text { Moderately } \\
\text { severe }\end{array}$ & 13 & 14 & 1 \\
\hline
\end{tabular}
the groups (Table 1).

VAS- Visual analogue scale

Pleural effusion was present in eight $(21 \%)$ in AG and seven $(18.4 \%)$ in NAG $(p=0.7)$. There was significant difference in $\mathrm{Hb}$, Urea and Creatinine in both the groups

\begin{tabular}{|c|c|c|c|}
\hline $\begin{array}{l}\text { Lab } \\
\text { parameters }\end{array}$ & $\begin{array}{l}\text { Antibiotic } \\
n(\%) \text { or Mean } \\
\pm \text { SD }\end{array}$ & $\begin{array}{l}\text { No Antibiotic } \\
\text { n (\%) or Mean } \\
\pm \text { SD }\end{array}$ & $\begin{array}{c}P \\
\text { value }\end{array}$ \\
\hline $\mathrm{Hb}(\mathrm{g} / \mathrm{dl})$ & $14 \pm 1.82$ & $12.92 \pm 2.03$ & 0.01 \\
\hline $\begin{array}{l}\text { Total count } \\
\text { (/cumm) }\end{array}$ & $9289.7 \pm 3307$ & $9135.9 \pm 2958.3$ & 0.82 \\
\hline $\begin{array}{l}\text { Urea (mg/ } \\
\text { dl) }\end{array}$ & $36.95 \pm 12.88$ & $52.05 \pm 17.57$ & 0 \\
\hline $\begin{array}{l}\text { Creatinine } \\
(\mathrm{mg} / \mathrm{dl})\end{array}$ & $0.99 \pm 0.30$ & $1.30 \pm 0.74$ & 0.01 \\
\hline ALT (IU/L) & $50.90 \pm 51.12$ & $42.97 \pm 19.53$ & 0.36 \\
\hline
\end{tabular}
(Table 2).

$\mathrm{Hb}$ - Hemoglobin, ALT - Alanine aminotransaminase 
Pancreatic necrosis developed in five (13.1\%) patients in AG and four (10.5\%) in NAG (Table 3).

\begin{tabular}{|c|c|c|c|}
\hline CECT & $\begin{array}{l}\text { Antibiotic } \\
\mathrm{n}(\%) \text { or } \\
\text { Mean } \pm \mathrm{SD}\end{array}$ & $\begin{array}{l}\text { No antibiotic } \\
\mathrm{n}(\%) \text { or Mean } \\
\pm \text { SD }\end{array}$ & $P$ value \\
\hline $\begin{array}{l}\text { Necrosis } \\
\text { Score }\end{array}$ & $5(13.1)$ & $4(10.5)$ & 1 \\
\hline Score 2 & 4 & 3 & \\
\hline Score 4 & 1 & 1 & \\
\hline $\begin{array}{c}\text { Normal } \\
\text { Parenchyma }\end{array}$ & $12(31.5)$ & $9(23.6)$ & \\
\hline Edema/AFC & $26(68.4)$ & $29(76.3)$ & \\
\hline
\end{tabular}

AFC - Acute Fluid Collection

Total of four (10.5\%) patients developed complications in the AG (two patients developed pneumonia, one UTI, and one hematemesis from splenic artery pseudo aneurysm), whereas in the NAG, one patient developed cellulitis, two developed pneumonia and two developed UTI. After the treatment was started, there was no difference in the final outcome in terms of earlier oral intake, length of hospital stay, complications, and mortality but there was significant difference in abdominal pain improvement (Table 4).

\begin{tabular}{|c|c|c|c|}
\hline Outcome & $\begin{array}{l}\text { Antibiotic } \\
\text { Mean days } \\
\pm \text { SD or } n \\
(\%)\end{array}$ & $\begin{array}{l}\text { No antibiotic } \\
\text { Mean days } \pm \\
\text { SD or } n(\%)\end{array}$ & $P$ value \\
\hline Oral intake & $3.26 \pm 2.06$ & $3.05 \pm 1.85$ & 0.64 \\
\hline $\begin{array}{l}\text { Improvement in } \\
\text { abdominal pain }\end{array}$ & $3.26 \pm 2.06$ & $2.44 \pm 1.07$ & 0.002 \\
\hline $\begin{array}{l}\text { Length of } \\
\text { hospital stays }\end{array}$ & $\begin{array}{l}7.77 \\
\pm 2.23\end{array}$ & $7.56 \pm 1.85$ & 0.65 \\
\hline $\begin{array}{l}\text { Complications } \\
\text { (extrapancreatic } \\
\text { infections) }\end{array}$ & $4(10.5)$ & $5(13.1)$ & 1 \\
\hline Mortality & $1(2.6)$ & - & 1 \\
\hline
\end{tabular}

\section{DISCUSSION}

Acute pancreatitis remains a common clinical condition requiring frequent admissions in Gastroenterological ward. The use of prophylactic antibiotics has been commonly seen in clinical practice in a country such as Nepal. The possible reason to prefer antibiotics could be unhygienic or contaminated working place as they are one of the potential sources of infection. In general, infectious complications from acute pancreatitis account for high morbidity and mortality with $80 \%$ of death related to infectious complications itself. ${ }^{5}$ The antibiotics which have found to achieve the highest inhibitory concentrations in pancreatic tissue are Carbapenems, Fluoroquinolones, Metronidazole, high dose Cefuroxime. ${ }^{8-11}$

In our study, alcohol is the commonest etiology of acute pancreatitis followed by gall stones. This finding is different from other study in which gall stones is the most common etiology followed by alcohol (38\% and $36 \%$ respectively). ${ }^{12,13}$ Alcohol is the most common cause in our study because drinking alcohol is commonly acceptable in most of our societies. Mean age of patients in our study was around 48 years which is comparable to other study carried out by Efstratios Koutroumpakis et al where mean age was 52 years. ${ }^{14}$

The age, sex, clinical severity of acute pancreatitis was similar in two groups. The overall incidence of infections in $A G$ and NAG was similar to the study done by Howes et al. ${ }^{12}$ However, the extra pancreatic infections observed in a study done by Rainer Isenmann et al was as high as $29 \%$ and $34 \%$ in AG vs. NAG respectively. ${ }^{4}$ Length of hospital stay in our study was 7.7 days in AG and 7.5 days in NAG. In our study, hospital stay was shorter in both groups as compared to the study done by Howes et al ( 9 in AG vs.12 in NAG). However, there was no significant difference between both the groups in that study. Others studies carried out by Finch et al, Pederzoli et al, Sainio et al, also showed no difference in both the groups. ${ }^{9,10,12,15}$

There was no infected pancreatic necrosis seen in our study as compared to other study where occurrence of infected pancreatic necrosis was as high as $17 \%$ and $14 \%$ in AG vs. NAG respectively. ${ }^{4}$ This may be because the number of patients with necrosis was less in our study. Average necrosis score was also lower in our study. Mortality in patients with necrotizing pancreatitis has been shown to be related to organ failure and not to severity of necrosis itself. 6,7

There was only one $(2.6 \%)$ death in our study in AG. This result is at the lower range than other studies where death rate was between 2-25\%. ${ }^{16,17}$ Lower mortality in our study can be explained by our inclusion of mild and moderately severe pancreatitis and recent better understanding in the management with aggressive hydration preventing pancreatic necrosis, less organ failure and therefore reduction in death. ${ }^{18-21}$

Our study showed no significant difference in the early initiation of oral intake in both the groups. In contrary, antibiotics use was associated with significant delay in the improvement of abdominal pain. This can be explained by the side effects of Metronidazole or ciprofloxacin resulting in abdominal pain and taking longer time than NAG. 
Our study could not find the role of prophylactic antibiotics in the prevention of pancreatic or peripancreatic infections in mild and moderately severe acute pancreatitis.

Our study had few limitations. We had lower sample size and patients were not followed up after hospital discharge.

\section{CONCLUSIONS}

Prophylactic antibiotic use in patients with mild and moderately severe acute pancreatitis is not associated with reduction in hospital stay, earlier oral feeding, pancreatic or peripancreatic infections. Hence, antibiotics should only be used if pancreatic or extrapancreatic infections are suspected or detected.

\section{REFERENCES}

1. Tenner S, Baillie J, DeWitt J, Vege SS. American College of Gastroenterology guideline: management of acute pancreatitis. Am J Gastroenterol. 2013;108(9):1400-15. [Full Text]

2. Sarr MG, Banks PA, Bollen TL, et al. The new revised classification of acute pancreatitis 2012. Surg Clin of North Am. 2013;93(3):549-62. [PubMed]

3. Dellinger EP, Tellado JM, Soto NE, et al. Early antibiotic treatment for severe acute necrotizing pancreatitis: a randomized, double-blind, placebo-controlled study. Annals of surgery. 2007;245(5):674-83. [PubMed]

4. Isenmann R, Rünzi M, Kron M, Kahl S, et al. Prophylactic antibiotic treatment in patients with predicted severe acute pancreatitis: a placebo-controlled, double-blind trial. Gastroenterology. 2004;126(4):997-1004. [PubMed]

5. Mourad M, Evans R, Kalidindi V, Navaratnam R, Dvorkin L, Bramhall S. Prophylactic antibiotics in acute pancreatitis: endless debate. Ann R Coll Surg Engl. 2017;99(2):107-12. [Full Text |DOI]

6. Wu BU, Johannes RS, Sun X, Tabak Y, Conwell DL, Banks PA. The early prediction of mortality in acute pancreatitis: a large population-based study. Gut. 2008;57(12):1698-703. [PubMed]

7. Johnson C, Abu-Hilal M. Persistent organ failure during the first week as a marker of fatal outcome in acute pancreatitis. Gut. 2004;53(9):1340-4. [Full Text | PubMed]

8. Büchler $M$, Malfertheiner $P$, Frie $\beta H$, et al. Human pancreatic tissue concentration of bactericidal antibiotics. Gastroenterology. 1992;103(6):1902-8. [PubMed]

9. Pederzoli P, Bassi C, Vesentini S, Campedelli A. A randomized multicenter clinical trial of antibiotic prophylaxis of septic complications in acute necrotizing pancreatitis with imipenem. Surg Gynecol Obstet. 1993;176(5):480-3. [PubMed]

10. Sainio V, Kemppainen E, Puolakkainen P, et al. Early antibiotic treatment in acute necrotising pancreatitis. The Lancet. 1995;346(8976):663-7. [PubMed]
11. Delcenserie R, Yzet T, Ducroix J. Prophylactic antibiotics in treatment of severe acute alcoholic pancreatitis. Pancreas. 1996;13(2):198-201. [PubMed]

12. Howes R, Zuidema GD, Cameron JL. Evaluation of prophylactic antibiotics in acute pancreatitis. J Surg Res.1975;18(2):197-200. [PubMed]

13. Wang G-J, Gao C-F, Wei D, Wang C, Ding S-Q. Acute pancreatitis: etiology and common pathogenesis. World J Gastroenterol. 2009;15(12):1427-30. [PubMed]

14. Koutroumpakis E, Slivka A, Furlan A, et al. Management and outcomes of acute pancreatitis patients over the last decade: A US tertiary-center experience. Pancreatology. 2017;17(1):32-40. [PubMed]

15. Finch WT, Sawyers JL, Schenker S. A prospective study to determine the efficacy of antibiotics in acute pancreatitis. Ann Surg. 1976;183(6):667. [Full text | PubMed]

16. Feller JH, Brown RA, Toussaint GPM, Thompson AG. Changing methods in the treatment of severe pancreatitis. Am J Surg. 1974;127(2):196-201. [PubMed]

17. Warshaw AL. Pancreatic abscesses. N Eng J Med. 1972;287(24):1234-6. [PubMed]

18. 18. Bradley EL, Allen K. A prospective longitudinal study of observation versus surgical intervention in the management of necrotizing pancreatitis. Am J Surg. 1991;161(1):19-25. [PubMed]

19. Tsiotos GG, Luque-de León E, Söreide JA, et al. Management of necrotizing pancreatitis by repeated operative necrosectomy using a zipper technique. Am J Surg. 1998;175(2):91-8. [PubMed]

20. Rau B, Pralle U, Uhl W, Schoenberg M, Beger H. Management of sterile necrosis in instances of severe acute pancreatitis. J Am Coll Surg. 1995;181(4):279-88. [PubMed]

21. Wall I, Badalov N, Baradarian R, Iswara K, Li JJ, Tenner S. Decreased mortality in acute pancreatitis related to early aggressive hydration. Pancreas. 2011;40(4):547-50. [PubMed] 